\title{
Chemically soluble fluoride in toothpastes marketed in Colombia
}

\section{Fluoruro químicamente soluble en cremas dentales distribuidas en Colombia}

\section{Fluoreto químico solúvel em cremos dentários distribuídos na Colômbia}

Lina María Marín ${ }^{1 凶} \underline{\text { ORCID }}$, Gina Alejandra Castiblanco $2 \bowtie \underline{\text { ORCID }}$, Margarita Usuga-Vacca $3 \otimes \underline{\text { ORCID }}$,

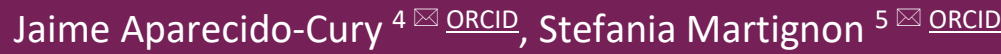

\footnotetext{
${ }^{1}$ Doctor in Dental Surgery, Master's degree in Biomedical Sciences, PhD in Dentistry, PhD in Biomedical Engineering. Salivary Proteomics Research Laboratory, College of Dentistry, University of Saskatchewan (Saskatoon SK, Canada) and Unidad de Investigación en Caries (UNICA), Research Vice rectory, Universidad El Bosque (Bogota D.C, Colombia).

2 Doctor in Dental Surgery, Master's degree in Biomedical Sciences, PhD Candidate in Dental Sciences. Department of Cariology, Preventive Dentistry and Dental Public Health, Indiana University School of Dentistry (Indianapolis, IN, USA) and Unidad de Investigación en Caries (UNICA), Research Department, Universidad El Bosque (Bogota D.C, Colombia).

${ }_{3}$ Doctor in Dental Surgery, Pediatric Dentist, Master's degree in Dentistry, PhD Candidate in Biomedical Sciences, Unidad de Investigacion en Caries (UNICA), Research Department, Universidad El Bosque (Bogota D.C, Colombia).

${ }^{4}$ Doctor in Dental Surgery, Master's degree in Biochemistry, PhD in Biochemistry, Departamento de Biociências Faculdade de Odontologia de Piracicaba -Universidade Estadual de Campinas FOP-UNICAMP (Piracicaba, SP Brazil).

5 Doctor in Dental Surgery, Pediatric Dentist, PhD in Cariology, Caries Research Unit (UNICA), Research Department, Universidad El Bosque (Bogota D.C, Colombia).
}

Fecha correspondencia: Recibido: enero de 2020. Aprobado: julio de 2020.

Forma de citar:

Marín LM, Castiblanco GA, Úsuga-

Vacca M, Aparecido-Cury J,

Martignon S. Chemically soluble

fluoride in toothpastes marketed

in Colombia. Rev. CES Odont

2021; 34(2): 3-14.

https://doi.org/10.21615/

cesodon. 5606

Open access

(C) Derecho de autor

Licencia creative commons

Ética de publicaciones

\section{Abstract}

Introduction and objective: Toothpastes should contain chemically soluble fluoride to have anti-caries efficacy. This study aimed at determining how much of the total fluoride (TF) concentration in the five top-selling children/family Colombiantoothpaste brands corresponds to total chemically soluble fluoride (TSF). Materials and methods: a convenience sample of three tubes of each of the following five toothpaste brands were obtained from three different chain stores, one-per-store, in five Colombian cities ( $n=3 /$ brand/city): Colgate-Smiles-6+, KolynosSuper-Blanco, Fortident-Cuatriacción, Colgate-Triple-Acción, Fluocardent. TF (sum of all toothpaste's fluoride) and TSF (toothpaste's chemically soluble fluoride) concentrations were determined in each fresh toothpaste sample (before expiry date) 
Revisión por pares

Gestión por Open Journal

System

DOI: $10.21615 /$ cesodon.5606

ISSNe 2215-9185

ISSN 0120-971X

Publica con nosotros

using a standardized ion-specific electrode direct-technique protocol. TF concentration was compared with the manufacturers' declared concentration. The difference between TF and TSF's concentrations purchased in different cities was compared with a one-way ANOVA (5\%). Results: Most toothpastes' TF concentration complied with what was declared in the label. One toothpaste had a non-compatible fluoride/abrasive fluoride formulation and TSF < TF; however, it still complied with the minimum TSF requirement to exert a caries-preventive effect (>1000 ppm). Toothpastes' TF and TSF concentrations did not differ between cities $(p>0.05)$. Conclusion: Fresh samples of highly distributed toothpaste brands sold in five Colombian- cities contain chemically available fluoride concentrations with the potential to control and prevent dental caries.

Keywords: toothpaste; sodium fluoride; calcium fluoride; dental caries.

\section{Resumen}

Introducción y objetivo: las cremas dentales requieren de la disponibilidad de fluoruro químicamente soluble para tener efecto anticaries. Este estudio tuvo como objetivo determinar qué parte de la concentración total de fluoruro (FT) en las cinco marcas de pastas dentales colombianas para niños/familias más vendidas corresponde al fluoruro total químicamente soluble (FTS). Materiales y métodos: se recolectaron tres tubos de cinco marcas diferentes en tres supermercados de cadena; una por tienda, en cinco ciudades colombianas ( $n=3 / \mathrm{marca} / \mathrm{ciudad})$ : Colgate-Smiles-6+, Kolynos-Super-Blanco, Fortident-Cuatriacción, Colgate-Triple-Acción, Fluocardent. Las concentraciones de FT y FST se determinaron en cada una de las muestras frescas utilizando técnica directa con electrodo específico y un protocolo estandarizado. La concentración de FT se comparó con la concentración declarada por el fabricante. Se compararon las diferencias entre las concentraciones de FT y FST de la misma marca compradas en diferentes ciudades a con un análisis ANOVA ( $\alpha=5 \%)$. Resultados: La mayoría de las cremas dentales cumplió con la concentración de FT declarada en la etiqueta. Una de las cremas dentale tenía una formulación de fluoruro/abrasivo no compatible y TSF <TF; sin embargo, aún cumplía con el requisito mínimo de TSF para ejercer un efecto preventivo de caries (> $1000 \mathrm{ppm}$ ). Las concentraciones de TF y TSF de las pastas de dientes no difirieron entre las ciudades ( $p>0.05)$. Conclusión: Las muestras frescas de cremas dentales de las marcas más vendidas en cinco ciudades colombianas contienen concentraciones de fluoruro químicamente disponibles con el potencial de controlar y prevenir la caries dental. 
Palabras clave: pastas de dientes; fluoruro de sodio; fluoruro de calcio; caries dental.

\section{Resumo}

Introdução e objetivo: os cremes dentais requerem a disponibilidade de fluoreto quimicamente solúvel para ter um efeito anticárie. O presente estudo determinou a proporção de fluoreto total (FT) que corresponde ao fluoreto total quimicamente solúvel (FST) em cinco marcas de creme dental amplamente distribuídas na Colômbia. Materiais e métodos: três tubos de cinco marcas diferentes foram coletados em três supermercados da rede; uma por loja, em cinco cidades colombianas ( $\mathrm{n}=3$ / marca / cidade): Colgate-Smiles- $6+$, Kolynos-SuperBlanco, Fortident-Quad, Colgate-Triple-Action, Fluocardent. As concentrações de FT e FST foram determinadas em cada uma das amostras frescas, utilizando a técnica direta com eletrodo específico e um protocolo padronizado. A concentração de FT foi comparada com a concentração declarada pelo fabricante. As diferenças entre as concentrações de FT e FST da mesma marca comprada em diferentes cidades foram comparadas com a análise ANOVA ( $\alpha=$ $5 \%)$. Resultados: a maioria das marcas possui concentrações de flúor que atendem à concentração declarada pelo fabricante. Uma marca contém uma formulação de sal abrasivo e fluoreto quimicamente não compatível e FST menor que FT; no entanto, as amostras frescas atenderam à concentração necessária para exercer um efeito anticárie (> 1000 ppm). As concentrações de FT e TSF não foram significativamente diferentes entre amostras da mesma marca compradas em diferentes cidades $(p>0,05)$. Conclusão: as amostras frescas (analisadas antes do prazo de validade) das cinco marcas de creme dental com maior distribuição na Colômbia contêm concentrações de fluoreto quimicamente solúvel, com potencial para controlar e prevenir a cárie dentária.

Palavras-chave: cremes dentais; fluoreto de sódio; fluoreto de cálcio; cárie dentária.

\section{Introduction}

Fluoride toothpastes are part of the category of topical, locally self-applied fluoride ${ }^{(1)}$. Although toothbrushing with fluoride toothpaste is considered as: i) the most rational way of use of fluoride to control caries ${ }^{(2)}$; ii) the reason for the caries prevalence decline observed in developed ${ }^{(3)}$ and, developing ${ }^{(4)}$ countries, and iii) the strongest way of fluoride use based on evidence ${ }^{(5)}$, problems with toothpaste formulations have been described worldwide ${ }^{(4,6-13)}$. According to the best available evidence ${ }^{(14)}$, the minimum fluoride concentration that a toothpaste should have to display its maximum caries-protective effect is $1000 \mathrm{ppm}(\mu \mathrm{g} \mathrm{F} / \mathrm{g}$ ), both for the primary ${ }^{(15)}$ and permanent dentitions ${ }^{(5,16)}$. In addition to interfere with the caries 
process - reducing demineralization and enhancing remineralization, the toothpaste's fluoride the must be chemically soluble in the formulation ${ }^{(17)}$.

Fluoride can be added into a toothpaste as sodium fluoride $(\mathrm{NaF})$, stannous fluoride $\left(\mathrm{SnF}_{2}\right)$, amine fluoride $(\mathrm{AmF})$, or sodium monofluorphosphate $\left(\mathrm{Na}_{2} \mathrm{PO}_{3} \mathrm{~F}=\mathrm{MFP}\right)$. Due to chemical incompatibility leading to the formation of insoluble fluoride salts, toothpastes with $\mathrm{NaF}, \mathrm{SnF}_{2}$ and $\mathrm{AmF}$ are not formulated with abrasives containing calcium ${ }^{(18,19)}$, and therefore are usually formulated with silica. When the toothpaste's formulation includes a calcium-based abrasive such as dicalcium phosphate dehydrate (DCPD) or calcium carbonate $\left(\mathrm{CaCO}_{3}\right)$, MFP is used as the source of fluoride. Although toothpastes formulated with MFP do not form insoluble salts with calcium-based abrasives during its manufacturing process, the MFP molecule is hydrolyzed during toothpaste's storage, releasing MFP ions that react with the calcium from the abrasive to form insoluble salts (insoluble fluoride, IF), reducing overtime the concentration of soluble caries-effective fluoride in the toothpaste ${ }^{(18)}$.

For regulatory purposes toothpastes are considered cosmetics that are sold over the counter and in most countries the regulations only specify the maximum of total fluoride (TF) concentration that a toothpaste should have, without specifying how much of it is soluble (20). Countries of the Andean Region (Colombia, Venezuela, Ecuador, Perú, and Bolivia) follow the FDA regulatory parameters of toothpaste's allowed ingredients ${ }^{(21)}$. In Colombia, the National Institute for the Surveillance of Foods and Drugs (INVIMA) performs periodic sanitary surveillance of oral hygiene products, with the only requirement being to assure that the concentration of TF in toothpastes does not exceed the maximum limit of $0.15 \% \mathrm{~F}$ $\left(1500\right.$ ppm F) ${ }^{(21)}$.

Given that only the only toothpaste-fluoride concentration controlled by Colombian regulatory bodies is the TF, and there is a lack of knowledge on the caries-preventive chemically soluble fluoride in toothpastes sold in Colombia, this study aimed at testing the quality of the top-selling toothpastes brands sold in five representative cities of the country, assessing both the toothpastes' TF and TSF fluoride concentrations.

\section{Materials and methods}

\section{Experimental design}

An exploratory study was conducted to assess the TF and TSF concentrations in the Colombian five top-selling toothpaste brands, one marketed for children: Colgate Smiles 6+ (A); and four 
marketed for family use: Kolynos Super Blanco (B), Fortident Cuatriacción (C), Colgate Triple Acción (D) and Fluocardent (E). Three tubes of each brand were bought in five cities representing the most populated regions of the country $(n=3 / b r a n d / c i t y)$ : North region (Cartagena); Andean region (Medellín and Bogotá); East region (Cali), and West region (Villavicencio). Toothpastes were obtained from three different national chain stores, one tube per chain store in each city. All toothpastes were analyzed before their expiry date.

\section{Determination of fluoride concentration}

The analyses were made in duplicates following a standardized protocol ${ }^{(6,7)}$. Briefly, an amount of $100 \mathrm{mg}$ ( $\pm 10 \mathrm{mg}$ ) of each toothpaste was weighted, vigorously homogenized in $10 \mathrm{~mL}$ of deionized water, and $0.25 \mathrm{~mL}$ of this suspension were transferred in duplicates to new plastic assay tubes for TF analysis (TSF + IF). The remaining suspension was centrifuged $(3,000 \times \mathrm{g} / 10$ min, room temperature) to remove the insoluble fluoride bound to the abrasive (IF). The volumes of $0.25 \mathrm{ml}$ of the supernatant were transferred in duplicate to new plastic assay tubes to determine fluoride ion's (Fi) and TSF's (F ion + MFP ion) concentrations. An amount of 0.25 $\mathrm{mL}$ of $2 \mathrm{M} \mathrm{HCl}$ were added to both tubes (TF and TSF) and after an incubation period of $1 \mathrm{~h}$ at 45 , ㄷ $\mathrm{C}$ the extracts were neutralized with $0.5 \mathrm{~mL}$ of $1 \mathrm{M} \mathrm{NaOH}$ and buffered with $1.0 \mathrm{~mL}$ of TISAB II. An amount of $1.0 \mathrm{ml}$ of TISAB II, $0.5 \mathrm{~mL}$ of $1 \mathrm{M} \mathrm{NaOH}$ and $0.25 \mathrm{~mL}$ of $2 \mathrm{M} \mathrm{HCl}$ was added to the Fi tubes. The concentration of TSF determined with this protocol ${ }^{(6,7)}$ was an indicator of bioavailable fluoride from in the MFP/ $\mathrm{CaCO}_{3}$ toothpaste ${ }^{(21)}$.

The concentration of fluoride ions was determined with an ion-selective electrode (Thermo Scientific Orion 96-09, Orion Research, Cambridge, MA, EUA) coupled to an ion analyzer Orion StarA214 (Orion Research, Cambridge, MA, EUA), previously calibrated with F standards having

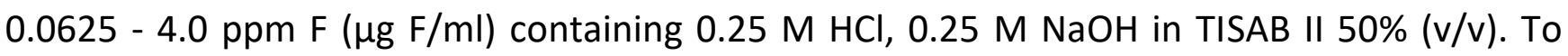
determine the fluoride concentration in the samples ( $\mu \mathrm{g} / \mathrm{g}$ ) a linear equation was determined to explain the relationship between the logarithm of the fluoride concentration found in the standards and the $\mathrm{mV}$ readings displayed by the ion analyzer $\left(r^{2}>0.999\right)$. The variation coefficient of the repeated analyses (duplicate) was $1.3 \%$. For data analyses, the means and standard deviations of the FT and FST concentrations found in each toothpaste brand sold in each city were calculated. In each sample, the IF concentration was calculated from the difference between FT and FST and expressed as the percentage of IF (\% IF). The MFP ion was determined by the difference between the TSF and the Fi. 


\section{Statistical analyses}

The percentage of disagreement between the measured and the declared TF was calculated by determining the proportion of the difference (TF declared - TF measured) that corresponds to the reference value (declared TF as 100\%). Both percentage of disagreement and descriptive statistics (means and standard deviations) were calculated using Exce ${ }^{\circledR}$ (Microsoft Corporation, Redmond, WA, USA). A disagreement $\geq 5 \%$ was considered as non-compliance (6). Differences between TF and TSF concentrations, as well as the \% IF, per brand, amongst the 5 different cities, were tested with ANOVA, using the software IBM SPSS Statistic 24 (IBM Corporation, Armonk, NY, USA). The significance level was set at $5 \%(\alpha=0.05)$; thus, a $p$-value $<0.05$ was considered to provide evidence of differences among the cities.

\section{Results}

Table 1 shows that four out of the five toothpaste brands (A, C, D, E) analyzed are formulated with $\mathrm{NaF}$ as fluoride salt and silica-based abrasives, while only one brand (B) contains a combination of NaF and MFP as fluoride salts and a calcium-based abrasive. Additionally, all the brands included in this study had a concentration of total fluoride higher than $1000 \mathrm{ppm} \mathrm{F}$, according to the information declared in the label by the manufacturer.

Table 1. Codification of the toothpaste brands selected, its fluoride salt, abrasive and declared fluoride concentration (ppm).

\begin{tabular}{ccccc}
\hline Brand & Code & $\begin{array}{c}\text { Fluoridated } \\
\text { agent }\end{array}$ & Abrasive agent & Declared F (ppm) \\
\hline Colgate Smiles 6+ & A & NaF & Hydrated silica & 1100 \\
\hline Kolynos Super Blanco & $\mathrm{B}$ & $\mathrm{MFP}+\mathrm{NaF}$ & Dicalcium phosphate dihydrate & $1450(1100 \mathrm{MFP} / 350 \mathrm{NaF})$ \\
\hline Fortident Cuatriacción & $\mathrm{C}$ & $\mathrm{NaF}$ & Silica & 1450 \\
\hline Colgate Triple Acción & $\mathrm{D}$ & $\mathrm{NaF}$ & Hydrated silica & 1450 \\
\hline Fluocardent & $\mathrm{E}$ & $\mathrm{NaF}$ & Hydrated silica & 1500 \\
\hline
\end{tabular}

TF concentrations found were between 1068.4 and $1462.1 \mathrm{ppm} \mathrm{F}$ (Table 2) while those declared by the manufacturer in the toothpastes' labels were between 1100 and 1500 ppm F. A disagreement higher than 5\% amongst measured and declared TF in the toothpaste brands $B$ and $E$ (5.3\% and $6.6 \%$, respectively) was found, being the measured TF concentration lower than that declared (Table 2). All toothpastes showed TSF concentrations above the minimum required to exert a caries-protective effect (> 1000 ppm F) (Table 2). 
Table 2. Total fluoride (TF), soluble fluoride (as fluoride ion, MFP ion and total fluoride) and percentage of insoluble fluoride $(\% \mathrm{Fl})$ found in the top-selling toothpastes sold in five representative cities in Colombia (mean \pm S.D., $n=3$ ).

\begin{tabular}{|c|c|c|c|c|c|c|c|c|}
\hline \multirow{3}{*}{ Brand } & \multirow{3}{*}{ Code } & \multirow{3}{*}{ City } & \multicolumn{2}{|c|}{$T F(p p m F)$} & \multicolumn{3}{|c|}{ Soluble fluoride (ppm F) } & \multirow{3}{*}{$\begin{array}{c}\% F I \\
\text { Mean SD }\end{array}$} \\
\hline & & & \multirow[t]{2}{*}{ Declared } & Measured & $F-$ & MFP & Total & \\
\hline & & & & Mean SD & Mean SD & Mean SD & Mean SD & \\
\hline \multirow{5}{*}{ Colgate Smiles $6+$} & \multirow{5}{*}{ A } & Medellín & \multirow{5}{*}{1100} & $1075.9 \pm 41.8 *$ & $1088.7 \pm 20.3^{*}$ & 0 & $1088.7 \pm 42.8 *$ & 0 \\
\hline & & Cali & & $1070.4 \pm 6.1 *$ & $1083.2 \pm 6.5 *$ & 0 & $1086.7 \pm 7.5^{*}$ & 0 \\
\hline & & Bogotá & & $1077.9 \pm 6.3^{*}$ & $1083.3 \pm 16.0 *$ & 0 & $1086.9 \pm 15.6 *$ & 0 \\
\hline & & Cartagena & & $1068.4 \pm 8.4 *$ & $1094.8 \pm 18.7^{*}$ & 0 & $1073.7 \pm 11.9 *$ & 0 \\
\hline & & Villavicencio & & $1078.8 \pm 10.2 *$ & $1100.7 \pm 21.0 *$ & 0 & $1084.9 \pm 6.4^{*}$ & 0 \\
\hline \multirow{5}{*}{$\begin{array}{l}\text { Kolynos Super } \\
\text { Blanco }\end{array}$} & \multirow{5}{*}{ B } & Medellín & \multirow{5}{*}{1450} & $1370.8 \pm 7.7^{*}$ & $370.8 \pm 18.8 *$ & $642.6 \pm 11.8 *$ & $1013.4 \pm 7.3^{*}$ & $26.1 \pm 0.6 *$ \\
\hline & & Cali & & $1368.8 \pm 11.2 *$ & $374.3 \pm 22.8^{*}$ & $626.6 \pm 20.6 *$ & $1000.9 \pm 18.5 *$ & $26.9 \pm 2.0 *$ \\
\hline & & Bogotá & & $1380.4 \pm 37.9 *$ & $388.8 \pm 3.1 *$ & $640.4 \pm 25.2 *$ & $1029.2 \pm 28.1 *$ & $25.4 \pm 0.1 *$ \\
\hline & & Cartagena & & $1431.3 \pm 60.9 *$ & $392.7 \pm 20.3^{*}$ & $688.7 \pm 45.2 *$ & $1081.4 \pm 65.5 *$ & $24.4 \pm 2.0 *$ \\
\hline & & Villavicencio & & $1344.9 \pm 15.5 *$ & $379.4 \pm 2.9^{*}$ & $625.4 \pm 5.3 *$ & $1004.8 \pm 2.4^{*}$ & $25.3 \pm 0.7^{*}$ \\
\hline \multirow{5}{*}{$\begin{array}{l}\text { Fortident } \\
\text { cuatriacción }\end{array}$} & \multirow{5}{*}{ C } & Medellín & \multirow{5}{*}{1450} & $1423.4 \pm 47.5 *$ & $1454.9 \pm 32.4 *$ & 0 & $1468.1 \pm 28.6^{*}$ & 0 \\
\hline & & Cali & & $1438.5 \pm 73.5 *$ & $1478.0 \pm 49.8 *$ & 0 & $1468.9 \pm 79.2 *$ & 0 \\
\hline & & Bogotá & & $1462.1 \pm 21.7 *$ & $1462.6 \pm 57.4 *$ & 0 & $1478.4 \pm 42.5 *$ & 0 \\
\hline & & Cartagena & & $1430.6 \pm 86.8 *$ & $1457.5 \pm 74.1 *$ & 0 & $1468.7 \pm 83.8 *$ & 0 \\
\hline & & Villavicencio & & $1415.7 \pm 9.6 *$ & $1435.4 \pm 32.8^{*}$ & 0 & $1440.2 \pm 12.9 *$ & 0 \\
\hline \multirow{5}{*}{$\begin{array}{l}\text { Colgate triple } \\
\text { acción }\end{array}$} & \multirow{5}{*}{$\mathrm{D}$} & Medellín & \multirow{5}{*}{1450} & $1375.3 \pm 25.3 *$ & $1400.8 \pm 18.0 *$ & 0 & $1398.0 \pm 22.2 *$ & 0 \\
\hline & & Cali & & $1406.2 \pm 29.9 *$ & $1444.1 \pm 12.6 *$ & 0 & $1418.1 \pm 23.5 *$ & 0 \\
\hline & & Bogotá & & $1413.7 \pm 33.1 *$ & $1438.4 \pm 10.2 *$ & 0 & $1442.1 \pm 29.3 *$ & 0 \\
\hline & & Cartagena & & $1384.5 \pm 3.6 *$ & $1427.4 \pm 9.7 *$ & 0 & $1411.3 \pm 15.1 *$ & 0 \\
\hline & & Villavicencio & & $1421.7 \pm 43.2 *$ & $1436.6 \pm 38.4 *$ & 0 & $1439.8 \pm 64.4 *$ & 0 \\
\hline \multirow{5}{*}{$\begin{array}{l}\text { Fluocardent Tiple } \\
\text { Acción }\end{array}$} & \multirow{5}{*}{$E$} & Medellín & \multirow{5}{*}{1500} & $1421.1 \pm 45.5 *$ & $1406.7 \pm 11.2 *$ & 0 & $1427.1 \pm 33.5 *$ & 0 \\
\hline & & Cali & & $1397.9 \pm 30.6 *$ & $1391.1 \pm 2.9 *$ & 0 & $1409.4 \pm 20.9 *$ & 0 \\
\hline & & Bogotá & & $1404.1 \pm 28.5 *$ & $1396.2 \pm 18.1 *$ & 0 & $1417.5 \pm 25.3 *$ & 0 \\
\hline & & Cartagena & & $1382.0 \pm 25.4 *$ & $1395.1 \pm 18.3 *$ & 0 & $1399.7 \pm 19.4 *$ & 0 \\
\hline & & Villavicencio & & $1401.0 \pm 38.6 *$ & $1398.8 \pm 41.1 *$ & 0 & $1413.5 \pm 28.2 *$ & 0 \\
\hline
\end{tabular}

$\mathrm{TF}=$ Total fluoride; $\mathrm{FI}$ = insoluble fluoride

* Statistically significant differences among cities for each toothpaste and analysis (ANOVA, $p<0.05$ ). 
The TF and TSF concentrations of the same toothpaste's brand, but purchased in different cities, were not statistically different $(p>0.05)$. Only one toothpaste had detectable levels of insoluble fluoride (brand B, 24.4-26.9\% IF) with no statistically significant differences among the cities ( $p>0.05)$ (Table 2).

\section{Discussion}

Most of the top-selling toothpaste brands sold in Colombia and analyzed in this study (A, C, D, E) contain NaF salt as source of fluoride and silica abrasive (Table 1), which are chemically compatible formulations. In this kind of formulation, all fluoride is potentially bioavailable to be delivered in the oral cavity during toothbrushing (7). On the other hand, toothpaste brand $B$ was formulated with a mixture of MFP and NaF and contained dicalcium phosphate dihydrate as an abrasive. Besides the fact that there is no evidence that toothpaste formulations combining MFP and NaF are effective as anti-caries agents, this formulation may be less compatible that MFP/ dicalcium phosphate dihydrate-based or MFP/calcium-carbonate-based formulations.

All toothpastes analyzed showed a TF concentration that were very close to the concentration declared in the label (Table 2). None of them displayed TF concentrations > 1500 ppm F, the maximum value allowed by Colombian regulations ${ }^{(21)}$. However, in terms of anti-caries benefits and dental fluorosis risk, it is relevant to know how much of the total fluoride is bioavailable, i.e. chemically available in the formulation to be released in the oral cavity during toothbrushing ${ }^{(7)}$ or to have a systemic effect when ingested $(7,22,23)$. Therefore, it is more important to know the total soluble fluoride (TSF) concentration contained in the toothpaste. The regulations followed by Colombia (a member of the Andean Region), fail in that they only establish the maximum TF concentration of the marketed toothpastes ${ }^{(21)}$. According to the best available evidence, a toothpaste should contain 1000 ppm F or more to have caries-preventive efficacy ${ }^{(5,14-16)}$ and is a fact that has been known for a long time ${ }^{(24,25)}$. Currently, based on the mechanism of action of fluoride, it is known it has to be soluble in the toothpaste's formulation ${ }^{(26)}$. Very few countries have guidelines controlling toothpastes marketing based on their soluble fluoride concentration (20) and according to the World Dental Federation (FDI), a toothpaste should contain at least 800 ppm of soluble fluoride ${ }^{(27)}$.

Our results show that all the toothpaste-brands evaluated in this study have a TSF concentration higher than 1000 ppm $F$ before its expiry date, irrespective of the region of the city where they were bought (Table 2). Furthermore, in toothpastes A, C, D and E, all fluoride was soluble $(\mathrm{TSF}=\mathrm{TF})$, in agreement with their chemically compatible formulations 
(NaF/Silica-based). Among the analyzed toothpastes, the only exception (although not surprising), was brand B. In this toothpaste, the measured TSF concentration was lower than the TF concentration (Table 2); with the difference probably attributable to insoluble salts formed between the fluoride ion and the $\mathrm{Ca}$ from the abrasive. Furthermore, in brand $\mathrm{B}$ the fluoride ion was already present as NaF since its manufacturing and very likely due to MFP hydrolysis that occurs overtime during its storage. In toothpaste $B$, an average of $25.6 \%$ of the total fluoride was insoluble (Table 2); in other words, it is caries-preventive inactive because it is not bioavailable. Considering that it was analyzed from fresh samples, it is very likely that by the end of the expiry date, this brand will not maintain an effective fluoride anti-caries concentration, as it has already been shown for MFP/calcium carbonate ${ }^{(28)}$. Therefore, it is advisable to evaluate this bran's fluoride concentration's stability over time.

Even though we have no exact data on the proportion of people using these specific brands in each city, the fact that these toothpastes are broadly distributed both in local and in national chain-stores, guarantees that these brands reach a significant portion of the population. The widely use of fluoridated toothpastes having a TSF concentration higher than $1000 \mathrm{ppm} F$ has vary likely contributed to the decline in the prevalence of dental caries experience that has been observed in Colombia from the first to the fourth National Oral Health Study (conducted in 1966 and 2015 , respectively) ${ }^{(29)}$. However, it is of our knowledge that locally produced oral healthcare products that are not approved, nor regulated, -and very likely not complying with regulations- are sold in the country, mainly in communities of low-socioeconomic status. Very little is known about the proportion of the population using such products and their impact in the prevalence of dental caries; thus, it would be interesting to survey the use of "nonconventional" toothpaste brands in Colombian communities where its marketing is suspected, to further analyze their quality.

\section{Conclusions}

Ttoothpaste brands highly distributed in five Colombian cities contain total fluoride concentrations that comply with Colombian regulations. Fresh samples from all toothpaste brands complied with the minimum chemically soluble fluoride concentration required for the prevention of dental caries, regardless of the purchase region. However, one toothpaste formulation containing $\mathrm{NaF}$ and dicalcium phosphate dehydrate as abrasive, had chemically soluble fluoride concentrations lower than the total fluoride, probably because of a nonchemically compatible formulation. The fluoride concentration in this toothpaste brand should be analyzed overtime to evaluate whether it maintains effective fluoride concentrations up to its expiry date. 


\section{Acknowledgements}

We are grateful to the delegates of the Colombian Association of Dental Schools (ACFO) who kindly helped with the collection of samples in the five Colombian cities.

\section{References}

1. Machiulskiene V, Campus G, Carvalho JC, Dige I, Ekstrand KR, Jablonski-Momeni A, et al. Terminology of Dental Caries and Dental Caries Management: Consensus Report of a Workshop Organized by ORCA and Cariology Research Group of IADR. Caries Res 2019; Oct 7:1-8. doi:10.1159/000503309.

2. Tenuta LM, Cury JA. Fluoride: its role in dentistry. Braz Oral Res 2010;24 Suppl 1:9-17.

3. Bratthall D, Hänsel-Petersson G, Sundberg H. Reasons for the caries decline: what do the experts believe? Eur J Oral Sci 1996;104 (4 (Pt 2)):416-422; discussion 423415,430-412.

4. Cury JA, Tenuta LM, Ribeiro CC, Paes Leme AF. The importance of fluoride dentifrices to the current dental caries prevalence in Brazil. Braz Dent J 2004; 15:167-174.

5. Marinho VC, Higgins JP, Sheiham A, Logan S. Fluoride toothpastes for preventing dental caries in children and adolescents. Cochrane Database Syst Rev 2003 (1):CD002278.

6. Cury JA, Oliveira MJ, Martins CC, Tenuta LM, Paiva SM. Available fluoride in toothpastes used by Brazilian children. Braz Dent J 2010; 21:396-400.

7. Martinez-Mier EA, Tenuta LMA, Carey CM, et al. European Organization for Caries Research Workshop: Methodology for Determination of Potentially Available Fluoride in Toothpastes. Caries Res 2018; 53:119-136.

8. Benzian H, Holmgren C, Buijs M, van Loveren C, van der Weijden F, van Palenstein Helderman W. Total and free available fluoride in toothpastes in Brunei, Cambodia, Laos, the Netherlands and Suriname. Int Dent J 2012; 62:213-221.

9. van Loveren C, Moorer WR, Buijs MJ, van Palenstein Helderman WH. Total and free fluoride in toothpastes from some non-established market economy countries. Caries Res 2005; 39:224-230. 
10. Fernández CE, Carrera CA, Muñoz-Sandoval C, Cury JA, Giacaman RA. Stability of chemically available fluoride in Chilean toothpastes. Int J Paediatr Dent 2017; 27:496505.

11. Kikwilu EN, Frencken JE, Mulder J. Utilization of toothpaste and fluoride content in toothpaste manufactured in Tanzania. Acta Odontol Scand 2008; 66:293-299.

12. Carrera CA, Giacaman RA, Muñoz-Sandoval C, Cury JA. Total and soluble fluoride content in commercial dentifrices in Chile. Acta Odontol Scand 2012; 70:583-588.

13. Giacaman RA, Carrera CA, Muñoz-Sandoval C, Fernandez C, Cury JA. Fluoride content in toothpastes commercialized for children in Chile and discussion on professional recommendations of use. Int J Paediatr Dent 2013; 23:77-83.

14. O'Mullane DM, Baez RJ, Jones S, Lennon MA, Petersen PE, Rugg-Gunn AJ et al. Fluoride and Oral Health. Community Dent Health 2016; 33:69-99.

15. dos Santos AP, Nadanovsky P, de Oliveira BH. A systematic review and meta-analysis of the effects of fluoride toothpastes on the prevention of dental caries in the primary dentition of preschool children. Community Dent Oral Epidemiol 2013; 41:1-12.

16. Walsh T, Worthington HV, Glenny AM, Appelbe P, Marinho VC, Shi X. Fluoride toothpastes of different concentrations for preventing dental caries in children and adolescents. Cochrane Database Syst Rev 2010:CD007868.

17. Cury JA, Tenuta LM. Enamel remineralization: controlling the caries disease or treating early caries lesions? Braz Oral Res 2009;23 Suppl 1:23-30.

18. Cury JA, Tenuta LM. Evidence-based recommendation on toothpaste use. Braz Oral Res 2014;28 Spec No:1-7.

19. Lippert F. An introduction to toothpaste - its purpose, history and ingredients. Monogr Oral Sci 2013; 23:1-14.

20. Cury JA, Caldarelli PG, Tenuta LM. Necessity to review the Brazilian regulation about fluoride toothpastes. Rev Saude Publica 2015;49. 
21. INVIMA. Resolución 797 de 2003. Reglamento de la Decisión 516 sobre Control y Vigilancia Sanitaria de Productos Cosméticos. Available from:

https://www.invima.gov.co/resoluciones-en-cosmeticos/resolucion-797-2004pdf/download.html. Accessed December 02, 2018.

22. Falcão A, Tenuta LM, Cury JA. Fluoride gastrointestinal absorption from Na2FPO3/CaCO3- and NaF/SiO2-based toothpastes. Caries Res 2013;47:226-33.

23. Oliveira MJ, Martins CC, Paiva SM, Tenuta LM, Cury JA. Estimated fluoride doses from toothpastes should be based on total soluble fluoride. Int J Environ Res Public Health 2013;10:5726-36.

24. Stookey GK. Are all fluoride dentifrices the same? In: Wei SHY. Clinical Use of Fluorides. Philadelphia: Lea \& Febiger; 1985. Chapter 9.

25. Hattab FN. The state of fluorides in toothpastes. J Dent 1989;17:47-54.

26. Tenuta LM, Cury JA. Laboratory and human studies to estimate anticaries efficacy of fluoride toothpastes. Monogr Oral Sci 2013;23:108-124.

27. FDI WDF. Promoting Dental Health through Fluoride Toothpaste, 2010. https://www.fdiworlddental.org/resources/policy-statements/promoting-dentalhealth-through-fluoride-toothpaste. Accessed December 02, 2018.

28. Cury JA, Vieira-Dantas ED, Tenuta LMA, et al. Fluoride concentration in most sold MFP/CaCO3 - based Brazilian toothpastes at the expiry time. Revista da Associação Paulista de Cirurgiões Dentistas 2015;69:248-251.

29. República de Colombia - Ministerio de Salud y Protección Social: IV Estudio Nacional de Salud Bucal ENSAB IV: Situación en Salud Bucal. Bogotá: Minsalud. 2015. Available from: https://www.minsalud.gov.co/sites/rid/Lists/BibliotecaDigital/RIDE/VS/PP/ENSAB-IVSituacion-Bucal-Actual.pdf 